\title{
6 MV Photon Beam Induced UV/VIS Absorption of Hema Polymer Gel
}

(Alur Foton 6 MV Teraruh Penyerapan UV/VIS Gel Polimer HEMA)

\author{
Siti ATIQAH ISHAK *, ISKANDAR SHAHRIM, SiTI, K.A.R. \& AZHAR A. ALRAHMAN
}

\section{ABSTRACT}

The aim of this study was to evaluate properties of normoxic polymer gel 2-Hydroxyethyl methacrylate monomer (HEMAG) as a point dosimeter by using optical properties evaluation techniques. HEMAG were prepared from seven different radiation dose within five different depths of HEMAG dosimeters. These HEMAG dosimeters were irradiated by linear accelerator with $6 \mathrm{MV}$ photon beams. The absorption spectra were measured by using a UV-visible spectrophotometer in the wavelength range from 300 to $800 \mathrm{~nm}$. Then, the data was analysed to determine the optical energy band gap ( $\left.E_{g}\right)$ and Urbach's energy $(\Delta E)$. The result showed that $\mathrm{E}_{\mathrm{g}}$ and $\Delta \mathrm{E}$ were dependent on radiation dose and percentage of depth dose (PDD). In additional, $\mathrm{E}_{\mathrm{g}}$ with indirect transition of HEMAG decreased as radiation dose increased and increased with traversing of depth. $\triangle \mathrm{E}$ of HEMAG increased as the dose increased and decreased with traversing depth of monomer. There was a shift in the $\mathrm{E}_{\mathrm{g}}$ values towards lower energy as the dose increased and led to a shift of the $\Delta \mathrm{E}$ value towards the higher energy with increasing dose. This observation supported the increase of structured disorder of the polymer with increasing radiation dose, which resulted in the lower energy transitions that was feasible and reduced the values of $\mathrm{E}_{\mathrm{g}}$. In conclusion, HEMAG has a potential to be used as a dosimeter at low radiation dose in the clinical radiotherapy.

Keywords: HEMAG; optical properties; optical band gap; polymer gel; Urbach energy; UV-vis spectrophotometer

\section{ABSTRAK}

Tujuan kajian ini ialah untuk menilai sifat poli-hidroksimetilakrilit gel (HEMAG) sebagai dosimeter titik dengan menggunakan teknik penilaian sifat optik. HEMAG disediakan daripada tujuh dos sinaran berbeza dilingkungi lima kedalaman dosimeter HEMAG yang berbeza. Dosimeter HEMAG dipersinarkan menggunakan pemecut linear dengan alur foton 6 MV. Spektra serapan diukur dengan menggunakan spektrofotometer UV-nampak pada julat panjang gelombang dari 300 hingga $800 \mathrm{~nm}$. Kemudian, data dianalisis untuk menentukan jurang jalur tenaga optik (E) dan tenaga Urbach ( $\triangle \mathrm{E})$. Keputusan menunjukkan $\mathrm{E}_{\mathrm{g}}$ dan $\triangle \mathrm{E}$ bergantung kepada dos sinaran dan peratus kedalaman dos (PDD). Sebagai tambahan, $\mathrm{E}_{\mathrm{g}}$ dengan transisi tak langsung HEMAG berkurang apabila dos sinaran meningkat dan meningkat dengan penyusuran kedalaman. $\mathrm{E}$ HEMAG meningkat apabila dos meingkat dan menurun dengan penyusuran kedalaman monomer. Terdapat anjakan di dalam nilai $\mathrm{E}_{\mathrm{g}}$ terhadap tenaga rendah apabila dos meningkat dan menjurus ke anjakan nilai $\triangle$ E terhadap tenaga tinggi dengan penigkatan dos. Pemerhatian ini menyokong peningkatan ketaktertiban berstruktur polimer dengan peningkatan dos, yang dihasilkan di dalam tenaga transisi rendah yang tersaur dan mengurangkan nilai-nilai Eg. Secara kesimpulan, HEMAG mempunyai potensi untuk digunakan sebagai dosimeter pada dos sinaran rendah di dalam radioterapi klinikal.

Kata kunci: Gel polimer; HEMAG; jalur tenaga optik; sifat optik; spektrofotometer UV-vis; tenaga Urbach

\section{INTRODUCTION}

Research in radiotherapy treatment has placed great demand upon current dosimetry techniques. The current and developed dosimeters, such as ionisation chambers, thermoluminescent dosimeters (TLDs) and radiographic film provide a different application (Cho et al. 2007). The studies of dosimeter for wide application are increased remarkably as alongside development of technology (Saion et al. 2005). Recently, researches propose that polymer gel records and integrates complex 3 dimensional (3-D) dose distributions. Polymer gel is also able to complete volumetric verification. This ability is rapidly investigated especially for treatment planning application in radiotherapy treatment (Cho et al. 2007). The absorption dose of polymer gel always is evaluated by imaging technique such as magnetic resonance imaging (MRI), computed tomography (CT-scan) and ultrasound due to covered volume scan of polymer gel (Maryanski \& Zastavker 1996). However, other evaluation techniques such as electronic absorption (UV-visible spectrophotometer), photoluminescence (PL), infrared red (IR) absorption, Raman scattering, dynamic light scattering, as well as time-resolved techniques, such as transient absorption and time-resolved luminescence can provide different information about the molecular properties of interest (Hawkins \& Holger 2014).

In this study, HEMAG gel was used where 2-Hydroxyethyl methacrylate (HEMA) acted as the monomer, THPC acted as anti-oxidant and $N, N^{\prime}-$ 
methylene-bis-acrylamide (BIS) acted as the cross-linker. The aim of this study was to evaluate the properties of normoxic polymer gel dosimeters as point dose dosimeter by using optical properties evaluation techniques.

\section{MATERIALS AND METHODS}

\section{MANUFACTURING OF HEMAG}

Polymer gels were prepared in atmosphere condition under fume chamber to reduce oxygen pre-interaction due to oxygen activation.

Firstly, $83 \%$ of the total amount of water was heated at $55^{\circ} \mathrm{C}$ in a hot plate magnetic stirrer unit. Then, $6 \%$ of BIS was added and the solution was stirred. After that, $8 \%$ gelatine powder was added and the solution was stirred until a clear solution was obtained. The solution was cooled to $30^{\circ} \mathrm{C}$ before HEMA and THPC were added. This target temperature was very crucial during gels preparation so chemical pre-interaction due to thermal activation can be reduced. Then, HEMA and THPC were stirred until a clear blend solution was obtained. The solution was fully poured into $4 \mathrm{~mL}$ ampoule tube with a dimension of $1 \mathrm{~cm}$ diameter and $4 \mathrm{~cm}$ height. The ampoule tube needed to be fully filled to minimize small contribution of air scattered that were irradiated by photon beam. The tubes were sealed with parafilm tape to minimize oxygen contamination through the cap of the ampoule tube. The gels were kept in a refrigerator at $4{ }^{\circ} \mathrm{C}$ and solidified within $24 \mathrm{~h}$ before exposures.

Irradiation of HEMAG The arrangements of polymer gel in phantom were shown in Figure 1, in which five HEMAG were irradiated collectively. Each gel was arranged in water tank, at water depth started from 1.5, 2.5, 3.5, 4.5 and 5.5 $\mathrm{cm}$, respectively. HEMAG dosimeter were irradiated with 6 MV photon beams by linear accelerator (Mevatron) at the center of phantom with field size of $10 \times 10 \mathrm{~cm}$ and 100 $\mathrm{cm}$ source to surface distance (SSD) toward a water tank dimension $30 \times 30 \mathrm{~cm} \times 18 \mathrm{~cm}$. Figure 1 shows a schematic diagram of the irradiated setup. Radiation dose given to HEMAG were 200, 400, 600, 800 and 1000 cGy.

Optical analysis of HEMAG After being measured by UV visible spectrophotometer, the absorption against wavelength was plotted. Previous studies by several researchers were referred for this study's data analysis of polymer optical properties, which determined optical energy band gap and absorption edge. Absorption coefficient $\alpha$ (v) of the HEMAG was taken from the optical absorption spectrum by using (1):

$$
\alpha(v)=2.303 \mathrm{~A} / \mathrm{d},
$$

where, $d$ is the sample thickness in $\mathrm{cm}$ and $A$ is the absorbance. Then a graph of $\alpha(v)$ against $h v$ was plotted at different doses.

TABLE 1 . The chemical compound of the HEMAG with a percentage mixture

\begin{tabular}{lc}
\hline Component & Concentration \\
\hline Gelatin & $6 \%$ \\
2-Hydroxyethyl methacrylate (HEMA) & $5 \%$ \\
Water & $83 \%$ \\
Tetrakis (hydroxymethyl) phosphonium chloride (THPC) & $5 \mathrm{mM}$ \\
N, N'-methylene-bis-acrylamide (BIS) & $6 \%$ \\
\hline
\end{tabular}

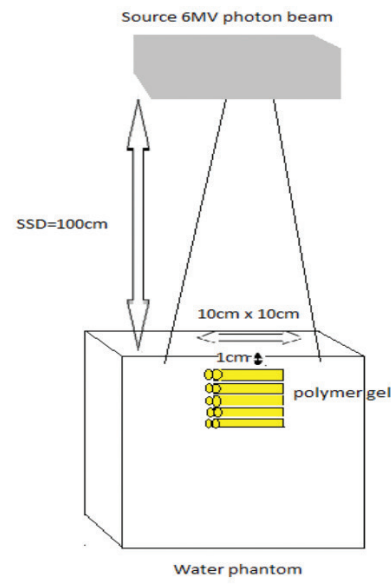

(a)

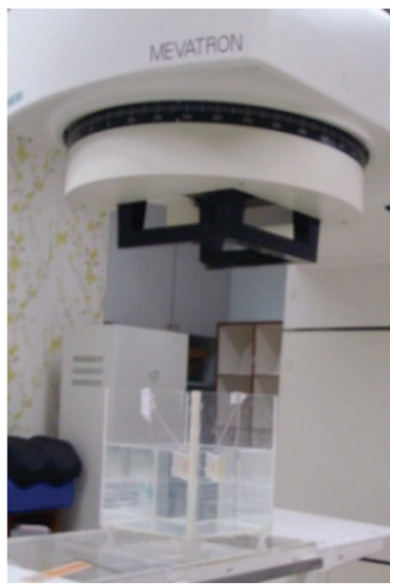

(b)

FIGURE1. Set of phantom for irradiated of photon beam:

(a) Illustration of set up and (b) real set up 
Analysis of the optical absorption spectra could reveal the optical energy gap $E_{g}$ between covalent band and the valance band due to direct and indirect transitions. The absorption coefficient $\alpha(v)$ is a function of photon energy that obeyed Mott and Davis model:

$$
\alpha(v) \hbar v=B(h v-E g)^{m},
$$

where $\hbar$ is the energy of the incident photon; $h$ is the Plank constant; $E_{g}$ is the optical energy band gap; $B$ is a constant and parameter $\mathrm{m}$ is the power coefficient with the value that determine by the type of possible electronic transitions; $m=2$ and $1 / 2$ for indirect and direct allowed transition, respectively.

The optical activation energy, $\Delta E$ is the energy width of the tail of localized states in the band gap was evaluated by using the Urbach-edges method given by the formula:

$$
\alpha(\omega)=\alpha_{o} \exp (h \omega / \Delta E)
$$

where, $\alpha_{o}$ is a constant and $\omega=2 \pi v$. The activation energy $\Delta E$ of irradiated samples were determined from the slope of the straight lines $\ln (\alpha)$ versus photon energy hn.

\section{RESULTS AND DisCUSSION}

\section{CHANGE IN AN ABSORBANCE AGAINST RADIATION DOSE AT DIFFERENT OF WAVELENGTH}

Plotted graph of absorbance amplitude unit (a.u.) against wavelength $(\mathrm{nm})$ for different radiation dose HEMAG were shown in Figure 2. The graphs showed similar pattern of optical absorbance spectra, of which the amount of light absorbed by the sample rapidly decreased in the range of wavelength generally within 314 to $510 \mathrm{~nm}$. The graph shifted to right as larger wavelength was produced and moved slightly closer to the border especially for higher absorption dose 800 and 1000 cGy shown in Figure 2(b). These results were slightly similar to previous study finding by Maryanski and Zastavker (1996) which discuss about the optical properties of polymer gel. The findings showed turbidity of optical absorbance spectra that apparently broaden with increasing dose and shift to the right. This is due to increasing of average size of the polymer particles with increase of radiation (Maryanski \& Zastavker 1996).

From the turbidity spectra shown in Figure 2(a), dose response curves were derived for three different wavelengths: 400, 500 and $600 \mathrm{~nm}$. Graph of absorbance (amplitude unit (a.u.)) against absorption dose (cGy) at $1.5 \mathrm{~cm}$ depth was plotted to determine of enhancement absorbance at different wavelength. Based on Figure 3, several connection were showing line pattern of dose response sensitivity which was interpreted as the change in optical absorbance against radiation with regression value (R-squared value) $0.939,0.932,0.919$ for 400,500 and $600 \mathrm{~nm}$ wavelength, respectively. The sensitivity can be significantly enhanced by using shorter wavelengths in which, the trade also showed with the changes 0.0005 , 0.0004 and 0.0003 with respective wavelength. This study found that dose response was sensitive at the shorter wavelength within highest $\mathrm{R}$-squared value. This result had similar finding in study by Maryanski et al. (1996) that also shows the dose response can be significantly enhanced by using shorter wavelengths.

Analysis of the absorption spectra could show the optical energy band gap $E_{g}$ or optical band gap between the convention band and the valence band due to direct and indirect transition. The HEMAG was only measured for indirect transition of optical band gap as (2). The indirect optical band gap could be evaluated from the linear plots of $(\alpha h v)^{1 / 2}$ against photon energy $h v(\mathrm{eV})$ in Figure 4. The extrapolation of the lines of $(\alpha h v)^{1 / 2}$ against 'hv' which $(\alpha h v)^{1 / 2}=0$, gave the indirect optical band gap which is a function of dose (Saion et al. 2005). Only small cut of wavelength were taken within range 390 to $420 \mathrm{~nm}$ to

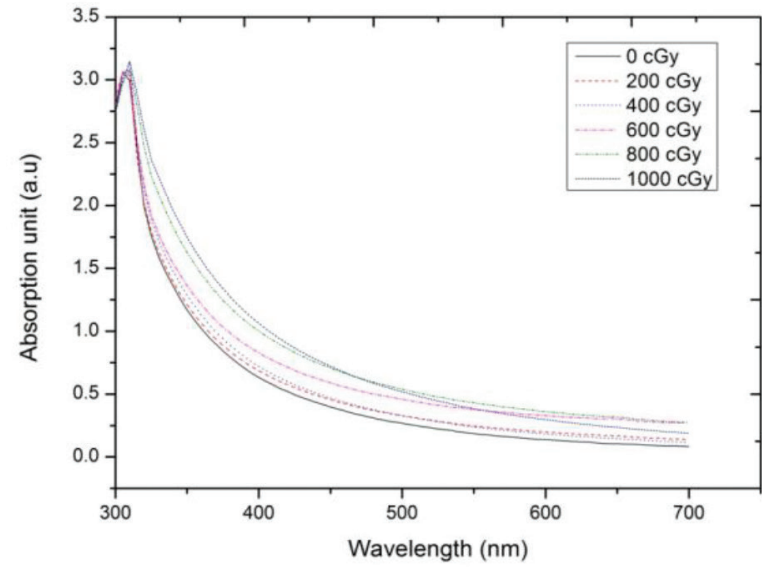

(a)

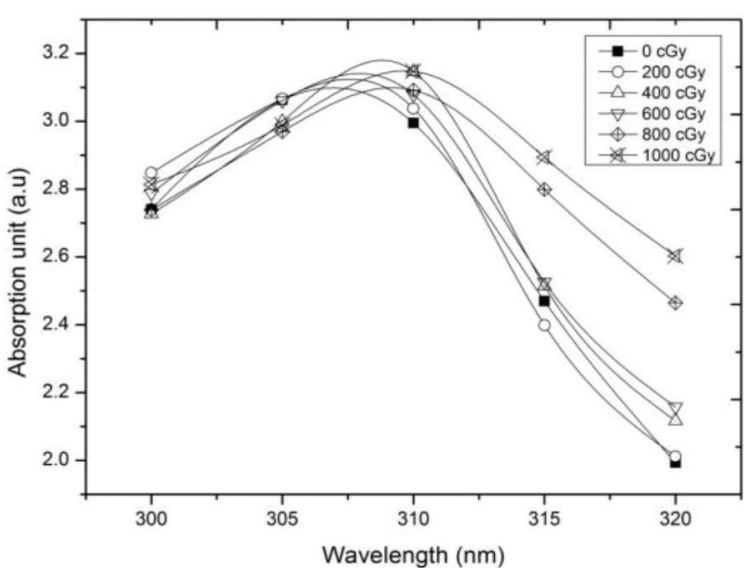

(b)

FIGURE 2. Variation of optical absorption spectra absorbance against photon energy (hv) of HEMAG for various doses: (a) original graph and (b) magnification graph scale from 300 to $320 \mathrm{~nm}$ 


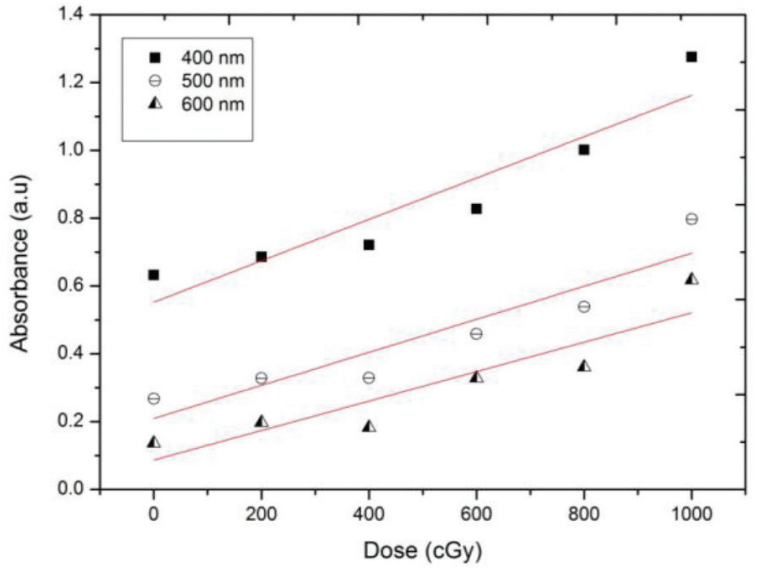

FIGURE 3. Variation of dose response curve at wavelength 400, 500 and $600 \mathrm{~nm}$ which the connection line is the gradient to defined dose response

determine optical band gap for each HEMAG. In addition, the dominant absorbance at $400 \mathrm{~nm}$ band of UV region increased with radiation dose showed in Figure 3.

Dose response of optical band gap Figure 5(a) shows the plotted graph of optical band gap $E_{g}$ against dose (cGy). The connection linear line showed the changes of pattern of dose response indirectly with optical band gap decrease with increasing dose with R-squared value 0.942 . These results had similar finding by Saion et al. (2005) as the $E_{g}$ decreased with increasing of exposure dose. Such a decrease in the value of $E_{g}$ could be attributed due to the increasing of polymerization, which formed the trap levels of energy states. Hence, the lower energy transitions became feasible and the optical band gap were reduced (Chahal 2011). In addition, study by Susilawati and Doyan (2009) showed a decrease in the optical band gap with increasing dose may be attributed to an increase in structural disorder of the polymer with increasing dose.

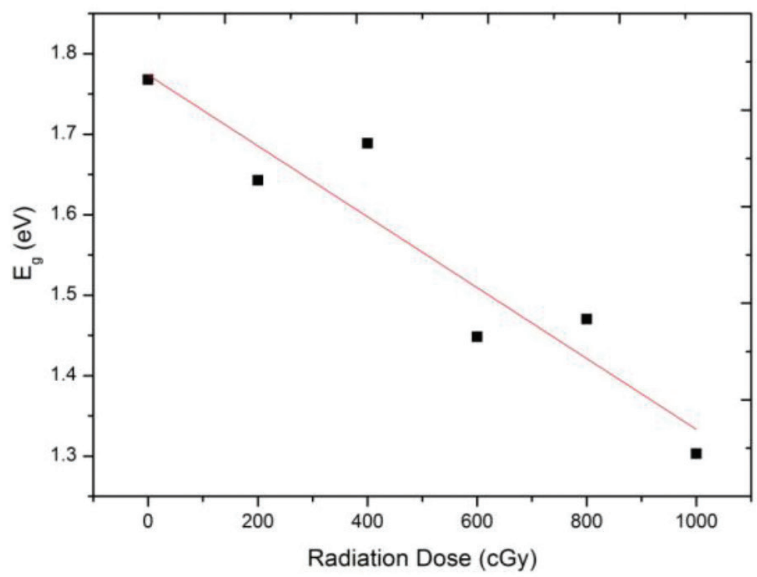

(a)

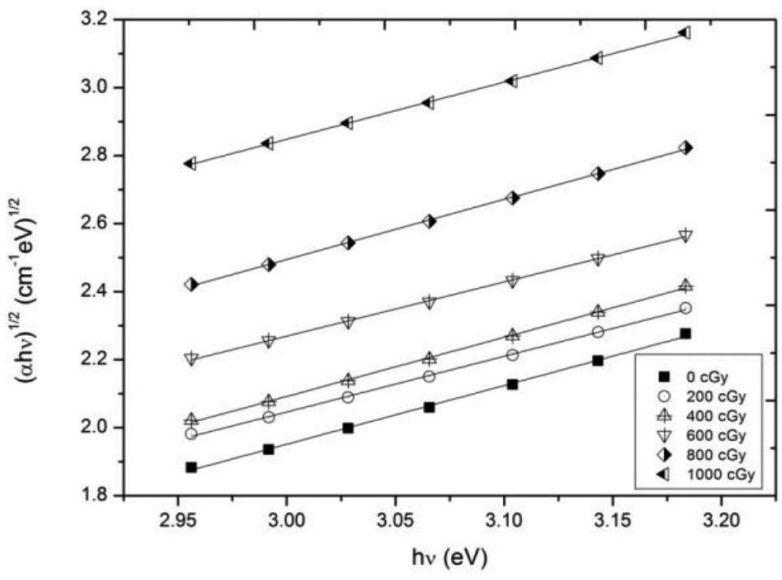

FIGURE 4. Variation of indirect transition $(\boldsymbol{\alpha} h v)^{1 / 2}$ against photon energy (hn) of HEMAG at various of radiation dose

Figure 5(b) shows the connection line pattern to show changes of optical band gap $E_{g}$ that was slightly decreased with increasing of traversing radiation depth with R-squared value 0.494 . Regarding the percentage depth dose (PDD), calibration absorption dose would decrease with depth due to increase in beam attenuation and it increase with field size due to the increment in scatter (Podgorsak 2005). Thus, absorption dose was slightly decreased with increasing depth from 1.5 to 5.5 $\mathrm{cm}$. Therefore, this result was valid with dose response which $E_{g}$ increased with decreasing of absorption dose.

The Urbach's energy, $\Delta E$ is the energy width of the tail of localized states in the band gap. This study evaluated $\Delta E$ by using the Urbach-edges method given by the formula in (3). The Urbach energy $\Delta E$ of irradiated samples were determined from the reciprocal slope $(1 / \mathrm{m})$ of the straight lines of logarithm of the absorption coefficient $\ln (a)$ versus photon energy $h n$ shows in Figure 6. Only small cut of wavelength were taken within range 390 to $460 \mathrm{~nm}$ to

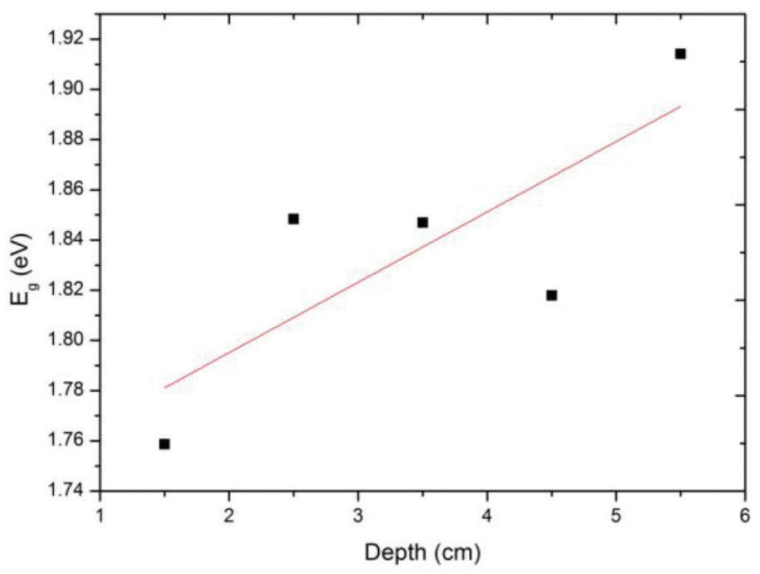

(b)

FIGURE 5. Variation of the optical band gaps with radiation dose (a) and depth (b) of HEMAG for various dose (cGy). Connection line; only shows the changes of $E_{g}$ with radiation dose (a) and depth and (b) to define the sensitivity in roughly 
determine Urbach energy for each HEMAG. The dominant absorbance at $400 \mathrm{~nm}$ band of UV region had increased with dose showed in Figure 3.

Dose response of Urbach's energy Figure 7(a) shows the plotted graph of Urbach's energy $(\Delta E)$ against radiation dose (cGy). The connection linear line showed the pattern changes of dose response with R-squared value 0.826 . From the line pattern, it was shown that $\Delta E$ decreased with increasing dose. These results were similar to previous study by Chahal et al. (2011) which the $\Delta E$ decreases with the increase of the radiation dose. The changes of depth response were plotted in Figure 7(b) and connection linear line showed indirect Urbach energy decrease with increasing depth with $\mathrm{R}$-squared value 0.431 . Thus, $\Delta E$ was dependent to radiation dose and traversing of radiation depth.

Figure 8 shows the relationship between the variations of the optical band gap $(E g)$ versus Urbach energy $(D E)$. Based on graph, energy band gap of HEMAG decreased with increasing radiation dose with R-squared value 0.93549 . This might be due to increasing structured disorder. Converting of monomer to polymer might increase structural disorder of the polymer due to increase radiation dose. Thus, the graph showed observation that supported the increase of structured disorder of the polymer with increasing radiation dose. This study found that, the lower energy transitions was feasible and reduced the values of optical band gap. This study had similar finding by previous study Chahal et al. (2011) which Urbach energy increases in correspond to the decrease in optical band gap.

\section{CONCLUSION}

HEMAG were evaluated by using UV visible spectroscopy to study the change of optical properties when irradiated to the low radiation dose. The results showed that $E_{g}$ and $\Delta E$ were

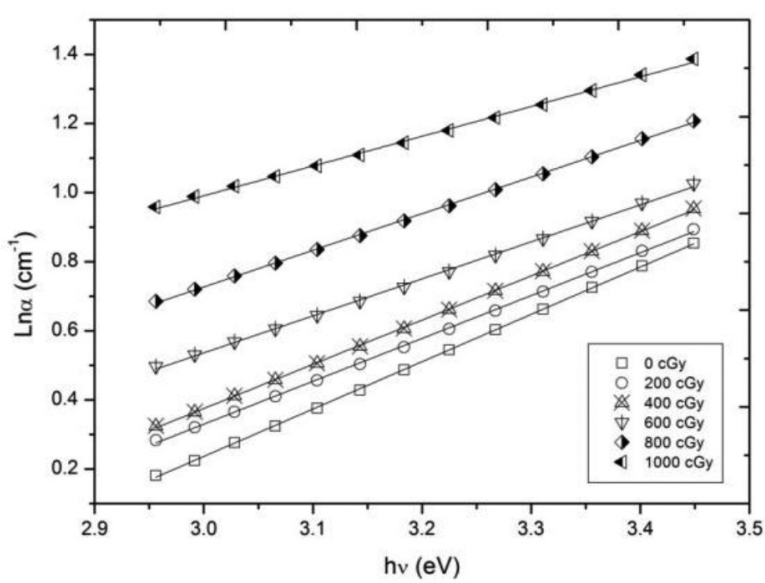

FIGURE 6. Variation of optical absorption coefficient $\ln \alpha\left(\mathrm{cm}^{-1}\right)$ against photon energy (hn) of HEMAG at various radiation dose

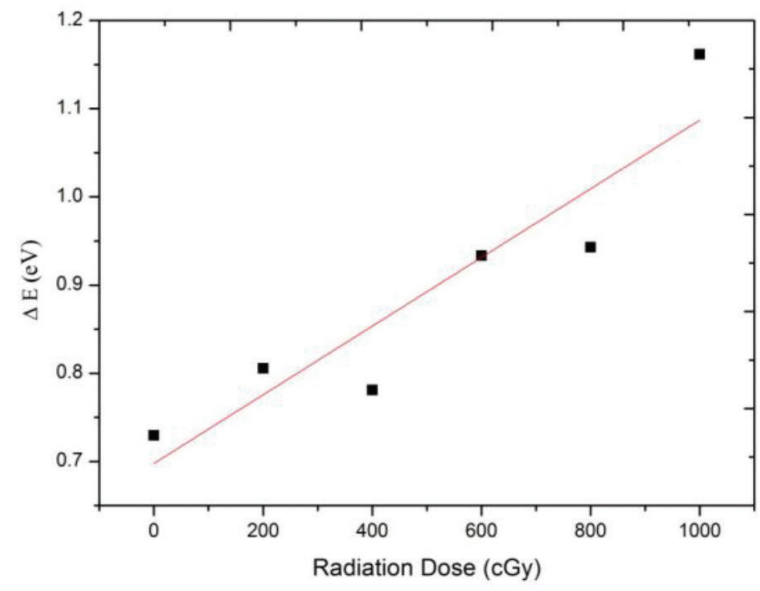

(a)

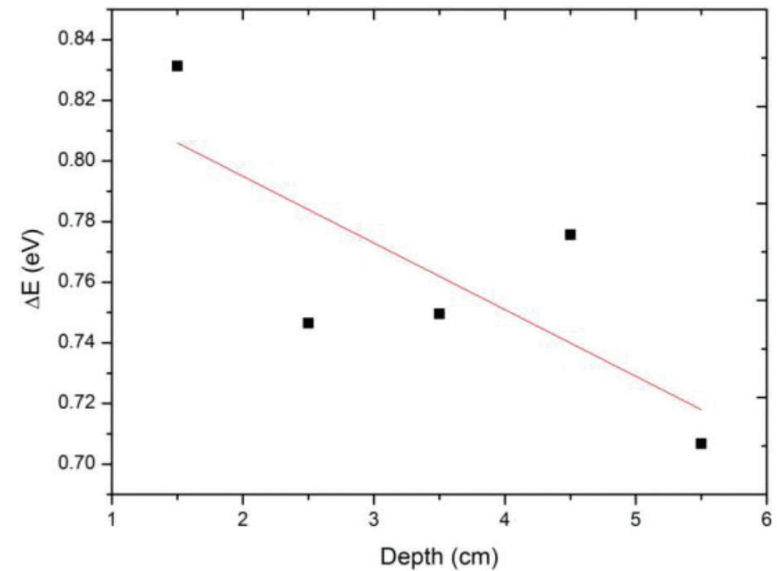

(b)

FIGURE 7. Variation of the Urbach energy. Connection line; only showed the changes of DE with

(a) dose and (b) depth to define the sensitivity in roughly 


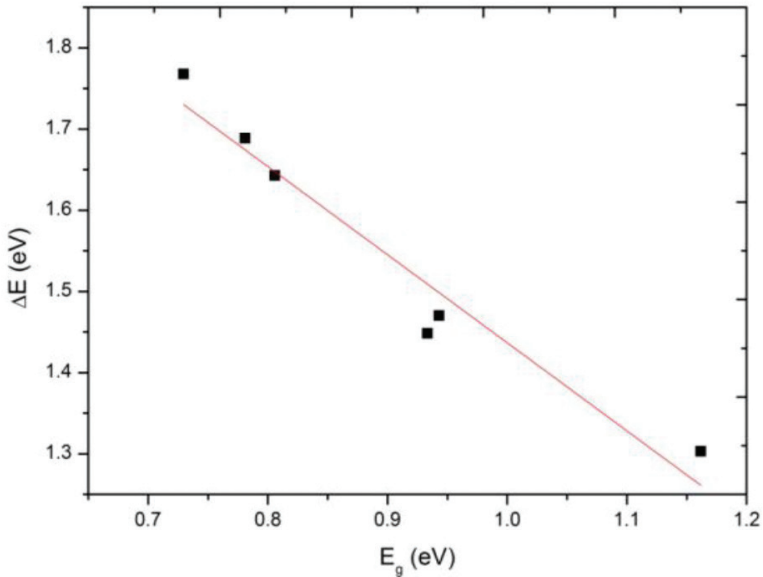

FIGURE 8. Variations of the optical band gap $(E g)$ versus Urbach energy $(D E)$

dependent response to absorption dose and irradiated depth. This study was showed that the sensitivity of the polymer gel due to the low radiation dose was improved by using a new composition (HEMAG) of polymer gel compared to the previous study and this was suitable to be used as an effective 3D dosimeter. However, some improvement should be done in order to reduce the percentage error of the measurement.

\section{ACKNOWLEDGEMENTS}

The financial support of the Research University Grant Scheme (RUI) from Malaysian Higher Education Department under vote 811301 is gratefully acknowledged. I would like express my gratitude to Mount Miriam Cancer Hospital for the usage of linear accelerator (LINAC) in completing the research.

\section{REFERENCES}

Chahal, R.P. 2011. Effect of ultraviolet irradiation on the optical and structural characteristics of in-situ prepared PVP-Ag nanocomposites. Digest Journal of Nanomaterials and Biostructures 6(1): 299-306.
Cho, S.J., Shin, D., Huh, H.D., Lee, S.H., Lim, S.W., Yun, H.G., Yun, S.M., Shin, D.O., Yang, D.S., Park, Y.J., Kim, C.Y. \& Lee, S. 2007. Development of a novel normoxic polymer gel dosimeter (TENOMAG). Journal of the Korean Physical Society 51(5): 1798-1804.

Elias Saion, Susilawati, Doyan, A., Zainal Abidin, S., Azmi, Z., Zulkfli, A., Mohd Zaki, A.R., Dahlan, K.Z.H. \& Karni, T. 2005. Changes in the optical band gap and absorption edge of gamma-irradiated polymer blends. Journal of Applied Sciences 5(10): 1825-1829.

Hawkins, A.R. \& Holger, S. 2010. Handbook of Optofluidics. New York: Taylor \& Francis Group. doi:10.1038/ncomms1662.

Maryanski, M.J., Zastavker, Y.Z. \& Gore, J.C. 1996. Radiation dose distributions in three dimensions from tomographic optical density scanning of polymer gels: II. Optical properties of the BANG polymer gel radiation dose distributions in three dimensions from tomographic optical density scanning of poly. Physic in Medicine and Biology 41: 2705-2717.

Podgorsak, E. 2005. Radiation Oncology Physics: A Handbook for Teachers and Students. International Atomic Energy Agency. doi:10.1038/sj.bjc.6604224.

Susilawati \& Doyan, A. 2009. Dose response and optical properties of dyed poly vinyl alcohol-trichloroacetic acid polymeric blends irradiated with gamma-rays. American Journal of Applied Sciences 6(12): 2071-2077.

School of Physics

Universiti Sains Malaysia

11800 USM Penang, Pulau Pinang

Malaysia

*Corresponding author; email: sitiatiqah.ishak@gmail.com

Received: 22 August 2014

Accepted: 24 May 2016 